\title{
TRADIÇÃO E INOVAÇÃO N'O NASCIMENTO DA TRAGÉDIA DE NIETZSCHE
}

Viriato Soromenho-Marques

\begin{abstract}
"(...) a tradição deve então ser compreendida igualmente como um conjunto de respostas sem questão, ou, mais exactamente, um conjunto de respostas que, ao velarem as questões de onde inicialmente surgiram, se velam a si mesmas como respostas".

João Paisana, Husserl e a Ideia de Europa, Lisboa, Edições Contraponto, 1997, p. 78.
\end{abstract}

\section{$\S 1$. A semente e a encruzilhada}

O Nascimento da Tragédia, publicado em 1872 (doravante NT), guarda um lugar especial, particularmente delicado e complexo, na obra de Nietzsche.

Através de NT, Nietzsche apresentou-se como autor à comunidade literária e intelectual do seu tempo. É uma primeira obra plena de promessas, mas também de algumas sombras, hesitações e equívocos.

1.1. Comecemos por uma aproximação formal e exterior. Este primeiro texto público, será, praticamente, o único de toda a vasta obra do pensador germânico a organizar-se em torno de uma estrutura mais clássica e convencional de desenvolvimento. Ao longo dos seus 25 breves capítulos há um conjunto coerente e limitado de teses que se exibem e procuram uma demonstração, com intenção e capacidade persuasivas, perante 0 público leitor.

Todas as outras obras fundamentais de Nietzsche, com a ressalva para o carácter peculiar de Assim falava Zaratustra e, noutra linha de orientação, da Genealogia da Moral, caracterizam-se por uma espécie de experimentalismo aforístico, um nomadismo reflexivo que evoca Montaigne e Pascal, um curso de meditação que não hesita em enveredar por múltiplas latitudes e perspectivas, sem fazer concessões a qualquer programa temático disciplinado e demonstrativo.

Não pretendo com isto afirmar que esta é a menos nietzscheana das obras de Nietzsche. Essa seria uma injustiça que nem os timbres mais severos do Ensaio de Autocritica, que em 18860 autor acrescentou como abertura à reedição da obra de 1872 permitiriam efectuar.

1.2. Com efeito, nesse texto tardio, quando Nietzsche já está na posse de todos os temas essenciais que individualizam o seu pensamento no firmamento filosófico, é possível destacar três tópicos de autocensura, que permitem assinalar, mesmo na diferença e na distância, aquilo que já existia de peculiar e único nesta obra. 
1.2.1. Em primeiro lugar, ao afirmar que NT estava "mal escrito" (schlecht geschrieben), Nietzsche sublinhava, ainda que pela negativa, aquela que será uma preocupação constante da sua obra, o cuidado estético e literário da sua escrita. Não admira que na sua correspondência com os editores e com os amigos essa intensa preocupação seja tantas vezes reiterada. No mesmo sentido deve ser lida a sua eloquente e perturbante premonição de despedida em Ecce Homo. Nesse texto, onde se escreve um balanço que o futuro revelaria mais testamentário do que prospectivo, é com a elegância de um Heinrich Heine que Nietzsche se mede, e não com prosa excessivamente longa de um Hegel, ou a expressão mais rigorosa que versátil de um Kant ${ }^{1}$.

1.2.2. Em segundo lugar, Nietzsche lamenta "não ter tido ainda nessa altura, a coragem (ou a falta de humildade?) para permitir-me [...] usar uma linguagem própria [...] ter penosamente procurado exprimir, com fórmulas schopenhauerianas e kantianas, juízos de valor estranhos e novos, tão fundamentalmente opostos ao espírito de Kant e Schopenhauer"2.

Qual o significado desta observação? Ela implica antes de mais que o Nietzsche de 1886 não renega o essencial do Nietzsche de 1871 e 1872 . O fundamental, o potencial, a semente para o germinar de um novo pensamento, o núcleo conceptual próprio já se encontrava inscrito em NT. Aquilo que envelheceu na década e meia seguinte foram os meios e os instrumentos de expressão. Com efeito, é assim que a referência elogiosa a Kant e Schopenhauer em NT se vê traduzida: não uma relação íntima de fidelidade do discípulo, mas uma relação utilitária e instrumental.

Em NT, esses dois grandes autores são meios para um objectivo que os transcende, são significantes que se esgotam na emergência de um significado inovador que visariam expressar. Kant e Schopenhauer não são referidos em função de uma economia hermenêutica que visasse a restituição da estrutura e da verdade das suas obras e sistemas. As suas obras são fonte de recursos, categorias e conceitos, usados em função de uma finalidade que é externa tanto ao texto como ao espírito do seu pensamento. Tal como Dioniso, Kant e Schopenhauer são máscaras onde se oculta o rosto de uma obra singular em busca do seu estilo próprio. Com a diferença de que Dioniso permanecerá, enquanto Kant e Schopenhauer passarão a fazer parte dos adversário teóricos predilectos do autor de NT.

1.2.3. A terceira observação autocrítica de Nietzsche que desejo sublinhar, refere-se às esperanças depositadas quinze anos antes, "onde nada havia a esperar" (wo Nichts zu hoffen war) $)^{3}$.

1 Todas as citações de $O$ Nascimento da Tragédia remetem para a seguinte edição portuguesa (ed. port): O Nascimento da Tragédia e Acerca da Verdade e da Mentira, Obras Escolhidas de F. Nietzsche, tradução de Teresa R. Cadete e introdução de António Marques, Lisboa, Relógio D'Água, 1997, Vol. 1.Todas as citações são também acompanhadas pela indicação da paginação relativa à edição alemã das obras do autor (doravante, KS): Kritische Studienausgabe, ed. Giorgio Colli e Mazzino Montinari, dtv/de Gruyter, Berlim, 1980, 15 volumes. Foi igualmente consultada a correspondência (doravante, SB): Friedrich Nietzsche Sämtliche Briefe. Kritische Studienausgabe in 8 Bänden, ed. Giorgio Colli e Mazzino Montinari, dtv/de Gruyter, Berlim, 1986. Sobre a crítica à escrita deficiente de NT: ed. port, p. 10; KS, Vol. 1, p. 14. Sobre a apreciação positiva de Heinrich Heine: Ecce Homo, KS, Vol. 6, p. 286.

2 NT, ed. port., p. 16. O texto completo da citação no original alemão é o seguinte: "Wie sehr bedauere ich es jetzt, dass ich damals noch nicht den Muth (oder die Unbescheidenheit?) hatte, um mir in jedem Betrachte für so eigne Anschauungen und Wagnisse auch eine eigne Sprache zu erlauben - dass ich mühselig mit Schopenhauerischen und Kantischen Formeln fremde und neue Werthschätzungen auszudrücken suchte, welche dem Geiste Kantens und Schopenhauers, ebenso wie ihrem Geschmacke, von Grund aus entgegen giengen!", KS, Vol. 1, p. 19.

3 NT, ed. port., p. 17; KS, Vol. 1, p. 20. 
O conceito abrangente dessas esperanças chamava-se Alemanha. Com efeito, Nietzsche não foi estranho ao grande entusiasmo nacional suscitado pela guerra franco-prussiana, e pelo posterior processo de unificação conduzido por Bismarck. Nota-se um orgulho contido na sua experiência como enfermeiro na margem sangrenta dos campos de batalha.

Contudo, e ao contrário da impressão errónea que ainda subsiste em muitas das recepções banais do Autor de NT, o seu idílio com a Alemanha foi de curta duração. à medida que ia avançando no seu pensamento. Como já tive ensejo de demonstrar noutros lugares, Nietzsche ia-se transformando mais em Europeu, reservando para os sonhos imperiais da jovem Alemanha uma crítica e fundamentada hostilidade ${ }^{4}$.

Contudo, a força motriz que fazia Nietzsche depositar esperanças na Alemanha em 1872 é a mesma força que o levará a desesperar dela e dos seus ícones. Em 1872 era grande a aposta num Wagner como restaurador musical, num cenário de modernidade, do espírito da tragédia esquiliana. Nietzsche chega a traçar a cartografia de uma constelação cultural alemã, onde brilhavam Bach e Beethoven, Kant e Schopenhauer. Até Lutero, tão maltratado mais tarde pelo filósofo, aparece visto com um olhar benevolentes.

O que fez Nietzsche mudar tão radicalmente de opinião, depois disso? A convicção - que a história demonstraria ser tristemente adequada - de que a Alemanha trocara a grandeza cultural, que implicava a abertura e o cosmopolitismo, pelos sonhos de hegemonia imperial, que forçava à crispação militar e ao isolamento nacionalista.

Ao longo da sua existência, Nietzsche não deixará de produzir numerosos sinais de hostilidade para com a "abdicação" e a "medianização" culturais da Alemanha. Contra as tendências chauvinistas dominantes exaltará o valor da ideia de Europa, escolherá o Sul como o seu centro de gravidade, preferirá os músicos italianos a Wagner, Maquiavel a Lutero. Celebrará Voltaire e Pascal, apesar do cristianismo deste último. Na Alemanha destacará o valor de Heinrich Heine e as virtudes intelectuais dos Judeus.

1.3. Um outro equívoco que importa desfazer desde logo diz respeito ao estatuto epistemológico de NT. Já muito se escreveu sobre as relações entre Nietzsche e a filologia clássica. Não será por esse caminho que o valor específico de NT merece ser considerado, pois, numa óptica estritamente filológica as teses de Nietzsche nem são radicalmente originais, nem suficientemente sólidas e fundamentadas ${ }^{6}$.

4 Viriato Soromenho-Marques, "Nietzsche e a Europa", Ao Encontro da Palavra-Homenagem a Manuel Antunes, Lisboa, Departamento de Letras da Faculdade de Letras da Universidade de Lisboa, 1985, pp. 203-214; Viriato Soromenho-Marques, "Nietzsche como pensador da política", Revista Portuguesa de Filosofia, volume 57, fasc. 2, Abril-Junho de 2001, pp. 260 -263 .

$5 \quad$ NT, ed. port. cap. 19, 131-141; cap. 23, 162-164: KS, Vol. 1, pp. 120-12, 147-149. Sobre a crítica de Nietzsche e o enquadramento de Lutero na modernidade: Viriato Soromenho-Marques, "A Reforma luterana no horizonte da filosofia política", Martinho Lutero. Diálogo e Modernidade, Frei Bento Domingues (ed.), Lisboa, Edições Universitárias Lusófonas, 1999, pp. 15-20.

6 Sobre as relações entre Nietzsche e a filologia clássica ver: António Marques, "O nascimento da suprema máscara: Dioniso", NT, ed. port., pp. LXXIX, e segs.; Viriato Soromenho-Marques, "A caracterização trágica do niilismo em Nietzsche" Dissertação de Mestrado, Lisboa, Departamento de Filosofia da Faculdade de Letras da Universidade de Lisboa, 1984, pp. 4-33. A valia filológica do NT de Nietzsche seria abertamente posta em causa pelo texto de um colega de Pforta, Ulrich von Wilamowitz-Moellendorf (1848-1931). Nessa polémica, que encontra um significativo registo na correspondência de Nietzsche (SB, Vol. 4, p. 6 e segs.) intervieram também Erwin Rhode e o próprio Wagner. Os textos capitais dessa polémica podem encontrar-se em: Karlfried Grunder (ed.), Der Streit um Nietzsches «Gerburt der Tragödie». Die Schriften von E. Rhode, U.v. Wilamowitz-Moellendorf, Hildesheim, Georg Olms Verlag, 1989. 
O que me parece ser realmente importante é a voluntária transição que o jovem Nietzsche efectua, e isso desde o início do seu magistério filológico em Basileia, da filologia para a filosofia.

Na sua aula inaugural, realizada em 28 de Maio de 1869, Nietzsche invertera uma frase de Séneca - mais uma vez o recurso a grandes figuras da tradição intelectual como instrumentos auxiliares para a expressão de um pensamento próprio-de modo a formular concisamente essa metamorfose e essa transição: (uit) $)^{7}$.

"Tornou-se filosofia o que era filologia" (Philosophia facta est quae philologia

NT inaugura assim o peculiar entendimento que Nietzsche faz da filosofia, como exercício de genealogias e prospecção de possibilidades, estéticas, éticas e gnosiológicas. A síntese desses múltiplos cambiantes é a ideia de cultura. Com efeito, NT é a ponta visível de um vasto e policromático fresco de reflexões nietzscheanas sobre o mundo e a "cosmovisão" (Weltanschauung) gregas. Ao pensar a Grécia, Nietzsche não o faz de um ponto de vista da historiografia (à qual dedicará uma das suas Considerações Intempestivas), mas antes como fisionomista da cultura, num diagnóstico do presente, das suas patologias e dos seus possíveis, sulcando um caminho que Rousseau (tão criticado por Nietzsche...) já trilhara e a que Oswald Spengler dará, no século XX, uma configuração sistemática. Uma via de pensamento a que Martin Heidegger ou Ernst Jünger também não se revelariam indiferentes.

1.4. Em NT afirma Nietzsche o primeiro esboço da sua concepção de filosofia como saber das possibilidades e dos valores da existência, como ontologia da experimentação de perspectivas inéditas e obras por realizar.

Ao serviço desta concepção de filosofia é preciso mais do que categorias e conceitos. Em NT, Nietzsche confere um direito de cidade definitivo ao mito como utensílio para o confronto crítico com as realidades do presente e sonda heurística dos possíveis abrigados no futuro.

Mais do que o fenómenos trágico grego, percebido a partir do crivo demasiado estreito permitido pela tecnologia dramática, o que está em causa em NT é a compreensão do significado plural, e pletórico para a cosmovisão helénica, representado pela dimensão e atmosfera míticas da tragédia. Na tragédia original sustentava Nietzsche que os gregos tinham atingido aquela capacidade, típica dos mitos, "de selar as suas experiências com a marca da eternidade" (seine Erlebnisse den Stempel des Ewigens zu drücken vermag). Como não ver aqui o modelo e o embrião dos temas nietzscheanos do futuro, tão prenhes de dimensões simbólicas e míticas, desde a "doutrina do eterno retorno do mesmo", às promessas do "super-homem", ou a vitória sobre a tutela de múltiplas faces do "niilismo"?".

Em NT, Nietzsche abria o seu próprio caminho, mesmo sob a máscara de cumplicidades teóricas que não resistiriam a uma análise mais cuidada, como já vimos relativamente a Kant e Schopenhauer.

Contudo, NT também acolhe afinidades inconfessáveis, nomeadamente, no que concerne ao reinvestimento filosófico do conceito de mito. Talvez sem o saber,

7 Curt Paul Janz, Friedrich Nietzsche. Infancia y juventud, trad. J. Muñoz, Madrid, Alianza Editorial, 1981, Vol. 1, p. 233. Sobre a atmosfera filológica e filosófica a partir da qual emergiu NT cf.: M. S. Silk e J. P. Stern, Nietzsche on Tragedy, Cambridge, Cambridge University Press, 1981, pp. 132-188. Sobre o autêntico processo de reinvenção da antiguidade levado a cabo por Nietzsche: James I. Porter, Nietzsche and the Philology of the Future, Standford, Standford University Press, 2000, pp. 32-81 e 225-290.

8 NT, ed. port., cap. 23, p. 163; KS, Vol.1, p. 148. 
o hegelianismo do jovem Nietzsche era ainda maior do que a sua reflexão retrospectiva de 1886 o admitia. Com efeito, já em 14 de Setembro de 1800 um outro jovem, o futuro autor da Fenomelogia do Espírito, tinha colocado o seu ideal de um sistema da razão sob o signo do vigor da arte e da polissemia mitológica:

“[...] o mais elevado acto da razão [...] é um acto estético [...] - Nós devemos ter uma nova mitologia, mas esta mitologia deve estar ao serviço das Ideias, deve tornar-se uma mitologia da razão"9.

\section{§ 2. O que era para Nietzsche essencial no fenómeno trágico helénico?}

NT é o texto central de um conjunto de escritos, na maioria inéditos, entre opúsculos e conferências, dedicadas por Nietzsche à cultura Grega nos anos de $1870 \mathrm{a}$ 1873, dominados pela sua docência universitária em Basileia.

O elenco desses ensaios é o seguinte:

- 'O drama musical grego'(Das griechische Musikdrama)

- 'Sócrates e a tragédia' (Socrates und die Tragoedie)

- 'A cosmovisão dionísiaca'(Die dionysische Weltanschauung)

- 'O nascimento do pensamento trágico'(Die Geburt des tragischen Gedanken)

- 'Sócrates e a tragédia grega'(Sokrates und die griechische Tragoedie)

- 'O combate de Homero'(Homer's Wettkampf)

- 'A filosofia na época trágica dos gregos'(Die Philosophie im tragischen Zeitalter der Griechen).

Para compreendermos o que de essencial se perseguia nessa reflexão torna-se necessário explicitar o axioma de partida em que se baseavam esses estudos, o qual é explicitado na Dedicatória de NT a Richard Wagner:

"[...] o facto de eu estar convicto da arte como sendo a missão superior e a actividade propriamente metafísica desta vida"10.

Nietzsche integrava-se, assim, na linhagem de grandes pensadores que na sequência da terceira Crítica kantiana, a essencial Crítica da faculdade de julgar (Kritik der Urteilskraft), passando pela dialéctica hegeliana do Espírito e do Saber, continuando na ontologia schopenhaueriana da vontade, procuravam aprofundar a dimensão filosófica essencial que se abrigava na experiência estética.

Para Nietzsche, o fenómeno da tragédia grega exibia a presença de duas forças essenciais, incapazes de serem subsumidas numa grelha conceptual redutora, designadas pelo nome de duas divindades:Apolo e Dioniso.

Muito mais importante do que o contributo para uma exegese do fenómeno exclusivamente helénico da tragédia, Apolo e Dioniso assumiam em Nietzsche um valor operatório universal e metafísico. Tornavam-se símbolos, configurações transbordantes e polissémicas, destinadas a expressar as múltiplas possibilidades e perspectivas da existência.

9 “[...] der höchste Akt der Vernunft [...] ein ästhetischer Akt ist [...] - Wir müßen eine neue Mythologie haben, diese Mythologie aber muß im Dienste der Ideen stehen, sie muß eine Mythologie der Vernunft werden". Hegel, "Systemfragment von 14. Sept. 1800", Hegel Werke in zwanzig Bänden, Eva Moldenhauer e Karl Markus Michel (eds.), Frankfurt am Main, Suhrkamp, 1970, Vol., I, p. 422.

10 "(...) dass ich von der Kunst als der höchsten Aufgabe und der eigentlich metaphysischen Thatigkeit dieses Lebens (...) überzeugt bin", NT, ed. port., p. 22; KS, Vol, 1, p. 24. 
Apolo e Dioniso são designações especificamente gregas, mas simbolizando modalidades profundas de criação cultural que rapidamente ganham características universais, o que permite acalentar o sonho do jovem Nietzsche de um renascimento alemão sob o signo dos valores da alma trágica helénica. Numa linha de orientação fortemente romântica e hegeliana, Nietzsche vai considerar essas duas divindades como estando firmemente vinculadas às raizes profundas do "génio do povo" (Volkgenius). Longe de serem expressão de uma cultura tardia, urbana e artificial, as duas divindades - transformadas em símbolos e axiomas hermenêuticos - traduzem as "pulsões de um povo" (Volkstriebe), "as forças éticas de uma Nação" (die ethischen Kräfte einer Nation $)^{11}$.

Apolo e Dioniso são, deste modo, símbolos da experiência mundana do homem grego, a qual se reflecte e determina de forma esclarecedora no domínio estético, e em particular na obra trágica. Apolo é a divindade originariamente helénica. É ela que fala ao longo do épico passado da poesia homérica. Cedo, porém, a melodia e a harmonia da flauta oriental, representante instrumental da orgia dionisíaca, vem perturbar a plástica rítmica da cítara ática, onde a música é trabalhada com o mesmo cuidado e regularidade com que a pedra é modelada na arquitectura dórica. Contudo, é nesse cruzamento que reside a riqueza da cultura grega, caracterizada pela sofreguidão pelo novo e pelo diferente, bem como pela capacidade de $\mathrm{o}$ absorver e integrar criativamente ${ }^{12}$.

Apolo, transformado em símbolo e em princípio, congrega a clareza solar, o gosto pela bela aparência, é a fonte do princípio de individuação, do recorte de entidades discretas, a justa medida, o sentido da proporção que se projecta na própria lógica do sonho. O elemento apolíneo volta-se para as formas, a cristalização, impera em tudo o que significa permanência e identidade. Daí que a razão, o $\log o s$, a vontade de analisar e distinguir, classificar orientar, lhe estejam subordinados ${ }^{13}$.

No luminoso mundo da exaltação e da aparência apolíneas, irrompe a subversiva força dionisíaca, anunciada pela melodia da flauta e os gritos delirantes dos participantes em festividades e orgias sazonais.

O princípio dionisíaco identifica-se com as forças nocturnas, com a dança, o fogo, o sacrifício. Em vez da tenaz perseverança na sua forma própria, na região ôntica que a cada ente parece reservada, o ditirambo dionisíaco transmite, através do canto do poeta no seu êxtase lírico, uma espécie de loucura topológica, as dilacerações e renascimentos de tudo o que existe e perecerá, para outra e outra vez ressurgir. As fronteiras da individuação e da qualificação, que permitem o exercício da razão calculadora, despedaçam-se sob o ímpeto orgiástico de Dioniso. Tudo está em tudo. Uma secreta comunhão ameça de desagregação os entes singulares, tal é a mensagem do perturbante princípio dionisíaco.

Duas notas finais devem ser retidas.

Em primeiro lugar, Apolo e Dioniso estabelecem uma dualidade, mas não um dualismo. O essencial do fenómeno trágico residia na manutenção da tensão entre esses dois símbolos ontológicos. Para Nietzsche, o crepúsculo da tragédia, que ele descreve como um processo endógeno, como um suicídio, ficou a dever-se, precisamente à ruptura dessa relação tensional. A busca da preponderância por parte do elemento apolíneo, que atravessou todas a cultura grega, visível tanto na obra dramática de Eurípedes como na filosofia socrática, acaba por destruir a vitalidade que ambos os princípios sinergeticamente retiravam da sua mútua relação.

Por outro lado, as interpretações dominantes do fenómeno helénico, muito concentradas no sublinhar desse elemento apolíneo da serenidade olímpica, enganavam-se quanto ao seu estatuto. Essa serenidade, constituía apenas a parte do todo, sendo um ponto de chegada e não um ingénuo ponto de partida. O que a serenidade grega,

1 KS, Vol. 7, 19 [2], p. 417 e 19 [16], p. 421.

12 NT, ed port., cap. 2, p. 32; KS, Vol. 1, p. 23

13 Die dionysische Weltanschauung, KS, Vol. 1, p. 553; Viriato Soromenho-Marques, 1984: p. 17 e segs. 
simultaneamente, contemplava e ocultava era o sentimento de horror perante o absurdo da existência, e a necessidade de o vencer para tornar a vida possível.

\section{§3. Há uma polémica oculta de Nietzsche com Aristóteles?}

De certa forma podemos afirmar que na reflexão nietzscheana sobre a decadência da tragédia existe um registo oculto que coexiste com um registo manifesto.

A tragédia suicidou-se, no plano manifesto, quando os heróis activos e prometeicos de tipo esquiliano deram lugar às figuras passivas, que não ousavam desafiar os deuses, antes se limitavam a sofrer passivamente o seu destino. É o caminho que vai de Ésquilo a Eurípedes. Que vai da preponderância do coro e da música para o peso do enredo e da fala, que vai da profundidade dos mistérios para a tranquilidade das explicações contidas na visibilidade dos argumentos, que vai da abrangência dos mitos para a vitória de uma lógica meramente representativa fundada no princípio da causalidade. Não admira que ao lado de Eurípedes se erga Sócrates, do mesmo modo que Heraclito habitava na vizinhança espiritual de Ésquilo.

O que surpreende, contudo, é que Nietzsche não tenha escolhido como alvo preferencial Aristóteles, pois é ele o autor da mais completa teoria da tragédia que a Antiguidade produziu, a Poética.

Nietzsche refere-se escassíssimas vezes a Aristóteles em NT. Talvez por não querer enfrentar um autor a quem ele reconhecia uma imortal grandeza, ou, talvez, por considerar não ser o Estagirita participante directo, mas tão só o cronista tardio do processo de degenerescência da tragédia antiga. Daí que tenhamos de reconstruir o seu possivel debate num registo manifesto e quase conjectural.

A diferença mais profunda entre Nietzsche e Aristóteles relativamente à concepção da tragédia é esta: o que para Nietzsche constitui uma marcha de decomposição e suicídio, nessa medida um percurso de empobrecimento e morte, constitui para Aristóteles um processo teleológico de amadurecimento e enriquecimento.

Com efeito, para Aristóteles - ao contrário de uma certa leitura Platão - a arte não pode ser considerada como uma actividade perigosa, construtura de ilusões sem substância. Para o Estagirita, a categoria central da arte poética, a categoria de imitação (mimésis), encontra-se impregnada de um forte conteúdo gnosiológico. A instância criadora da arte mimética mergulha sobre um mundo plural de criaturas, um caos de entes e personagens desprovidos de univocidade. $\mathrm{O}$ artista deve tentar desocultar o segredo, a verdade que as coisas guardam dentro de si, pois Aristóteles recusa, como é sabido, o dualismo platónico. A medida das coisas deve ser retirada do seu interior. Desse modo, o artista realiza uma tarefa de certa forma semelhante à do filósofo, embora de inferior dignidade onto-gnosiológica. $\mathrm{O}$ artista tem de mergulhar no mundo concreto para, através de um processo de abstracção, eliminação e selecção, reter aquilo que de essencial sobrevive no crivo da experiência.

Assim como a verdade filosófica reside nos elementos universais captados e estruturados no conceito, também a mimésis poética deve realizar uma acção de fixação dos componentes representativos capazes de colocarem o espectador da tragédia numa situação emocional de expectativa. A arte poética, ao seleccionar apenas uma parte dos elementos formais disponíveis na matéria-prima dramática, revela-se como desempenhando uma função propedêutica relativamente à filosofia. Com efeito, aquilo que o espectador anseia presenciar na tragédia tem uma dimensão universal. A arte mimética habita na vizinhança do universal, aproximando-se com isso da demanda filosófica da verdade, constituindo-se como uma antevisão simbólica dessa verdade ${ }^{14}$

14 Aristóteles, Poética, IV, 1048b 20-1049 a 28.Viriato Soromenho-Marques, 1984: pp. 34-44. Ainda sobre as relações entre Nietzsche e Aristóteles, M. S. Silk e J. P. Stern, 1981, pp. 225-238 . 
É neste esforço aristotélico de valorização da arte poética que, curiosamente, se vai situar a divergência fundamental de Nietzsche face a Aristóteles. Ao considerar a tragédia inserida na órbita de um esforço gnosiológico, Aristóteles vai sobrestimar os elementos e as instâncias preponderantes no teatro de Eurípedes, isto é, os elementos unilateralmente apolíneos, reduzindo o fenómeno da tragédia da condição de obra total e participativa, sagrada, que segundo Nietzsche ela tinha sido no seu auge esquiliano, para um simples espectáculo ao serviço da inteligibilidade do enredo e do entendimento do espectador.

Com efeito, enquanto Nietzsche procurava acentuar a dimensão musical garantida pela presença do coro, e destacava na atitude do espectador o acto de partilha e participação, activa e envolvida, em toda a estrutura da obra trágica, a interpretação aristotélica, pelo contrário, concentrava-se na acção sustentada pelos argumentos da trama e do enredo. A música ficava reduzida a um complemento, a um adereço suplementar. $\mathrm{O}$ espectador era convidado não ao envolvimento e à comunhão, mas simplesmente ao acompanhamento exterior, através do entendimento. A catarse era o análogo da conclusão das premissas de um silogismo.

Em Aristóteles era a redução socrática e moral da tragédia que triunfava. O que para Nietzsche constituía um processo endógeno de decadência, um suicídio, resultava para o Estagirita, pelo contrário, na actualização das potencialidades contidas nas formas originais do drama grego. $\mathrm{O}$ que para o grande pensador grego consistia uma realização plena, era, na perpectiva do autor germânico, o crepúsculo da tragédia, a destruição da polaridade vital entre as forças apolíneas e dionisíacas, a subordinação de um registo amplo e polissémico às exigências de uma estética estritamente racionalista, submetida à economia de uma filosofia dominada pela soberania do entendimento e pelo primado do dever-ser moral.

\section{$\S 4$. O que deve Nietzsche a Schopenhauer n'O Nascimento da Tragédia?}

A formulação mais contundente sobre as relações entre Nietzsche e Schopenhauer no quadro do NT estão contidas numa concisa exclamação do Ensaio de Autocritica (1886):

“(...) como estava outrora longe de mim justamente todo esse resignacionismo!"15.

Se é verdade que o 'espírito' da obra de Schopenhauer, aquilo que Niestzsche designa por 'resignacionismo', se encontrava, efectivamente muito longe do aparente discípulo de 1872, a verdade é que o texto de NT está perpassado de marcas nítidas da forte influência, pelo menos, da 'letra' da metafísica de Schopenhauer. E isso a dois níveis diferentes:

a) O jovem autor utiliza abundantemente a dicotomia conceptual da "vontade e representação" (Wille und Vorstellung), que constitui a medula teória da filosofia de Schopenhauer, e que aparece claramente no título da sua obra capital, "O mundo como vontade e representação" (Die Welt als Wille und Vorstellung-1818) ${ }^{16}$.

15 “(...) wie ferne war mir damals gerade dieser ganze Resignationismus", NT, ed. port., pp. 16-17; KS. col. 1, p. 20. Sobre a relação entre Nietzsche e Schopenhauer, em particular, no âmbito do NT: Georges Goedert, Nietzsche der Überwinder Schopenhauers und des Mitleids, Amsterdam, Rodopi B. V., 1988, pp. 25-61.

$16 \mathrm{Um}$ dos aspectos mais curiosos da proximidade de Nietzsche perante Schpenhauer situa-se na tese que considera a música como expressão directa e imediata da própria vontade: Schopenhauer, Die Welt als Wille und Vorstellung (doravante: WWV), Sämtliche Werke, ed. 
b) Mesmo a visão de Kant em NT está muito marcada pelo peso da interpretação que o pensador de Frankfurt traçara do autor da Crítica da razão pura.

Mas o que pensa Schopenhauer sobre a tragédia? A tragédia, à semelhança de todos os outros domínios da actividade estética, serviria, a seu modo, para o desvendamento das clivagens do mundo dos fenómenos e das representações, em que a existência mergulha. As obras de arte, embora de forma desigual, seriam portadoras de um valor gnosiológico, revelariam os diversos graus de objectivação da "vontade" (Wille) - a essência inesgotável e insondável do Ser - no campo fenoménico da representação (Vorstellung). Esses graus são designados por Schopenhauer como "ideias" (Ideen) 17.

Esta tese, que aponta para um horizonte neoplatónico de participação entre as duas instâncias ontológicas centrais da cosmovisão de Schopenhauer (a vontade e a representação), dá-nos conta da forma peculiar como se transformou o sentido original da dicotomia kantiana entre "fenómeno" (Erscheinung) e "coisa-em-si" (Ding-an-sich). Ao introduzir a dimensão intermédia das "ideias" (Ideen), de acento vincadamente neoplatónico, Schopenhauer visa criar uma instância de mediação entre os planos da vontade e da representação, o que seria impensável no quadro da diferença conceptual kantiana acima referida.

Para Schopenhauer, a tragédia é o "cume da arte poética" (der Gipfel der Dichtkunst). Ela contribui para levantar o 'véu de Maia', que obscurece a revelação do segredo íntimo das coisas, que esconde a sua dependência ontológica fundamental relativamente à vontade, considerada como o substracto radical do existente. Pela tragédia, através do doloroso e cruel destino dos personagens do drama, liberta-se perante o nosso olhar a verdadeira essência da vida, que na perspectiva de Schopenhauer conduz para o sublinhar da total vacuidade do sofrimento, da inútil aposta nas coisas e nas causas que povoam o nosso quotidiano. À semelhança do divertissement pascaliano, esse entusiasmo pelas coisas e pelas causas, criaria uma capa protectora, que nos esconde o vórtice abissal e absurdo das vidas singulares ${ }^{18}$.

Para destacar que o objectivo da tragédia é "a exposição dos lados terriveis da vida" (die Darstellung der schreklichen Seiten des Lebens), Schopenhauer agrupará em três modalidades as produções dramáticas possíveis no âmbito da tragédia:

a) Aquela em que o desfecho terrível já está anunciado na carácter desafiadoramente violento e vibrante dos personagens principais (tal é o caso, por exemplo, das peças de Shakespere, Othelo e Mercador de Veneza).

b) Um segundo tipo, em que parece ser a cega brutalidade do acaso, a força conducente ao infortúnio (o Rei Edipo, de Sófocles, parece ser o 'caso mais clássico).

c) Uma última categoria, em que a desgraça final parece derivar exclusivamente do simples relacionamento dos personagens entre si, isto é, da pura existência.

A verdadeira essência sem esperança da existência, o fundamento ontológico do pessimismo só se revela verdadeiramente, segundo Schopenhauer, na última modalidade de tragédia.

Sobre essa modalidade, escreve o pensador de Frankfurt:

"Esta última espécie de tragédia parece-me muito mais preferivel do que as outras duas; porque ela nos mostra a maior desgraça não como uma excepção, não como algo

W. F. von Löhneysen, Darmstadt, Wissenschaftliche Buchgesellschaft, 1968, Vol. 2, pp. 573-586). Nietzsche é tributário desta concepção: NT, ed. port., cap. 6, p. 52; KS, Vol. 1, p. 51. 
provocado por raras circunstâncias ou por caracteres monstruosos, mas como algo que nasce fácil e espontaneamente das acções e dos caracteres humanos, como algo que quase lhes é essencial e que precisamente desse modo é trazido terrivelmente perto de nós"19.

Deste modo, a essência do trágico manifesta-se no seio da vida quotidiana. Sob a aparentemente tranquila repetição dos mesmos actos e dos mesmos gestos, agita-se a verdade terrível da vida, o seu insondável absurdo. O estigma trágico não constitui o excepcional mas sim o comum, não é o distante mas aquilo que jaz na proximidade, não é o fruto do insólito, mas a presença do familiar.

A conclusão de Schopenhauer explicita-se no que podemos considerar um ambíguo registo ético da tragédia.

Escreve ele:

"O verdadeiro sentido da tragédia é a mais profunda apreensão que aquilo que o herói expia não são os seus pecados particulares, mas o pecado original, i.e. a culpa da existência"20.

Na verdade, a distância entre Schopenhauer e Nietzsche não poderia ser maior!

A teoria schopenhaueriana da tragédia coloca-nos face aos limites do seu confessado ateismo. A sua cosmovisão de uma vontade informe e sedenta, traduzindo-se e destruindo-se como uma Fénix no mundo dos fenómenos e das representações, apresenta-nos um universo sem Deus e sem esperança, mas totalmente percorrido pela nostalgia de Deus e da salvação.

Enquanto, como já vimos, para Nietzsche a tragédia grega, e o fenómeno trágico em sentido mais geral, constituíam perspectivas libertadoras de possibilidades inauditas da existência, convites à acção criadora e aventurosa, para Schopenhauer a tragédia era a dramática confirmação do destino de demissão e de desistência a que, como epílogo, conduzia o seu pessimismo.

Em Schopenhauer não havia já lugar para o Deus cristão, mas o juízo sombrio, negativo, condenatório sobre a existência, 'vale de lágrimas e tentações', produzido pela moral cristã permanecia intacto na pena do autor d'O mundo como vontade $e$ representação.

Ao contrário da resignação e da renúncia schopenhauerianas, a lição que o jovem Nietzsche retirava da tragédia antiga apontava para a aposta exaltada e prometeica numa vida intensa e activa. A própria confrontação com o que surgia como um absurdo sem remissão era entendida por Nietzsche como a prova de fogo suprema da liberdade.

Já nos escritos da mais fresca adolescência encontramos a ressonância afirmativa de uma liberdade, que através do exercício da vontade (o amadurecimento da reflexão nietzscheana transformá-la-á em vontade de poder) se transforma em necessidade consentida e autoconstruída.

Curiosamente, a melhor formulação do enorme afastamento intelectual entre os dois filósofos é proferida por Nietzsche quando este, na sua terceira Consideração Intempestiva, efectua uma apologia, que é, simultaneamente, uma despedida de Schopenhauer.

19 "Diese letztere Art scheint mir den beiden andern weit vorzuziehen: denn sie zeigt uns das größte Unglück nicht als eine Ausnahme, nicht als etwas durch seltene Umstände oder monströse Charaktere Herbeigefährtes, sondern als etwas aus dem Tun und den Charakteren der Menschen leicht und von selbst, fast als wesentlich Hervorgehendes, und führt es ebendadurch furchtbar nahe an uns heran", WWV, Vol. I, pp. 355-356.

20 "Der wahre Sinn des Trauerspiels ist die tiefern Ëinsicht, daß, was der Held abbüsst, nicht seine Partikukarsünden sind sondern die Erbsünde, d.h. die Schuld des Daseins selbst", WWV, Vol. 1, p. 354. 
Com efeito, aí não é a renúncia que encontramos, mas sim a tenaz afirmação dos valores de uma vida plena, heróica e responsável. Escrevia Nietzsche:

"Nós temos de assumir perante nós próprios a responsabilidade da nossa existência; por isso nós queremos ser também os verdadeiros pilotos desta existência, e não permitir que ela se assemelhe a um absurdo acaso"21.

O que começamos a encontrar, já nos textos de Nietzsche sobre a tragédia, é mais do que a diferença entre o pessimismo moral de Schopenhauer e a estética do trágico do jovem professor d Basileia. O mais relevante, já nesses anos de autodescoberta, é a diferença entre um pensamento que se encarniça na negação da "vontade de viver", e um outro que faz do crescimento e expansão criadoras dessa vontade o seu autêntico objectivo.

O que começamos a vislumbrar nesse pensamento embrionário do início da década de 1870, é a vontade concebida como força positiva e afirmativa, como princípio para além dos cânones morais, como antecâmara do que será uma das ideias centrais da ontologia de Nietzsche: a "vontade de poder" (Wille zur Macht).

\section{$\S 5.0$ que deve Nietzsche a Hegel n'O Nascimento da Tragédia?}

Poucos meses antes do seu colapso intelectual, publicava Nietzsche esse estranho livro que se intitula Ecce Homo, onde, entre outras coisas, é possível encontrar uma auto-avaliação do seu, já vasto, percurso intelectual.

A dado passo, no exíguo espaço concedido a NT, escreve Nietzsche sobre a presença de Hegel nesse texto de 1872: Hegelisch $)^{22}$.

"Ela [a obra NT] cheirava indecentemente a hegelianismo" (sie riecht anstößig

O juízo é inteiramente justo, embora a metáfora não seja das mais correctas. $\mathrm{Na}$ verdade, a dimensão olfactiva aplica-se mais a Schopenhauer, pois os pontos de afinidade são da ordem de um superficial perfume, enquanto os pontos de contacto com Hegel são, de longe, mais íntimos e substanciais.

Desde logo é possível identificar os seguintes tópicos de afinidade conceptual entre os dois pensadores germânicos:

- Ambos sentem a necessidade de ultrapassar os limites da capacidade expressiva das categorias e dos conceitos Quando Nietzsche recorre às divindades de Apolo e Dioniso, ou quando Hegel recorre ás famosas "figuras" (Gestalten) da Fenomenologia do Espirito) o que está em causa são as limitações semânticas de uma metafísica construída na penosa arquitectura das categorias.

- Tanto Hegel como Nietzsche não se satisfazem com o paradigma de um entendimento calculador. A dialéctica da razão hegeliana - valorizada face ao saldo

21 "Wir haben uns über unser Dasein vor uns selbst zu verantworten: folglich wollen wir auch die wirklichen Steuermänner dieses Daseins abgeben uns nicht zulassen, daß unsere Existenz einer gedenklosen Zufälligkeit gleiche", Unzeitgemässe Betrachtungen-III-Schopenhauer als Erzieher, KS, Vol. 1, p. 339.

22 Ecce homo, KS, Vol. 6, p. 310 . Sobre a relação entre Nietzsche e Hegel: M. J. Carmo Ferreira, "Hegel e Nietzsche. Hermeneutas da modernidade", Nietzsche: cem anos após o projecto "Vontade de poder - Transmutação de todos os valores», António Marques (org.), Lisboa, Vega, 1989, pp. 111-132; Stephen Houlgate, Hegel, Nietzsche and the Criticism of Metaphysics, Cambridge, Cambridge University Press, 1988, pp. 24-37 e 182-221. 
negativo da "dialéctica transcendental" kantiana - e a crítica do 'socratismo' e do cientismo em Nietzsche vão nesse sentido.

- Ambos os autores rejeitam como modelo para o rigor filosófico a matriz explicativa físico-matemática, propondo em alternativa uma valorização do que poderemos considerar uma ordem simbólica do discurso e uma adequação de tipo compreensivo.

- Por último, ambos os autores colocam a temporalidade e a história no centro das suas cosmovisões. O próprio Nietzsche reconheceria que em NT a "oposição" (Gegensatz) apolíneo-dionisíaca se tinha transformado num princípio de hermenêutica histórica.

O jovem Hegel, amigo de Hölderlin, foi sensível, como o seria mais tarde o jovem Nietzsche, ao fascínio da cultura e da filosofia gregas. A dimensão trágica da existência não poderia ter escapado a um pensador tão profundo, habitando numa época de dilaceração, entre as esperanças cosmopolitas da Revolução Francesa e a formação das ambições nacionalistas na sequência das guerras napoleónicas e da Restauração.

Também Hegel se encontrava decepcionado com os limites de dois séculos de cartesianismo, como paradigma quase incontestado, da filosofia europeia. A verdade era mais do que aquilo que o entendimento poderia representar, Ela era mais do que o que poderia ser conhecido no seio dos fenómenos. Contudo, Hegel não poderia ignorar o risco que Kant denunciara aos precursores do romantismo. O risco de tombarem na perigosa mescla de misticismo e preguiça, própria da intuição intelectual.

O caminho que Hegel vai percorrer tentará evitar os múltiplos obstáculos, as tentações e ciladas no caminho do pensamento. Quando no dealbar do seu sistema, Hegel vai procurar traduzir a essência da verdade filosófica ele afastar-se-á. simultaneamente, tanto da pobreza da "representação" (Vorstellung) como da riqueza precipitada da intuição intelectual. A verdade é um processo, lento, complexo e doloroso. É uma "exposição" (Darstellung). Para a actualizar são precisos mais do que conceitos, mais do que abstracções. Curiosamente, o jovem construtor de sistemas irá recorrer à linguagem dionisíaca que Nietzsche usará quase sete décadas depois:

"O fenómeno é o nascer e perecer que nele próprio não nasce nem perece, mas sim existe em si e constitui a realidade e o movimento da vida da verdade. O verdadeiro é assim o delírio báquico"23.

A atitude dialéctica de Hegel e a interrogação pelo trágico do jovem Nietzsche coincidem quando colocam a demanda filosófica sob o signo da totalidade. A vida é interrogada em busca de um excesso de sentido, de uma plenitude de possibilidades. Mas é nesse elemento comum que se afere a diferença decisiva entre esses dois modos de interrogar o existente. O modelo trágico não reconhece a possibilidade de uma progressiva interpenetração integrativa das determinações possibilitadas pelo trabalho da razão. Para Nietzsche, a atitude trágica implica a aceitação duma fissura que nunca se preencherá, de um antagonismo que jamais se reconciliará.

Para Hegel, o carácter trágico da existência, manifestado no perecer dos entes singulares que a mais elementar experiência exibe, poderia ser superado pelo assumir, por parte da razão, da sua vocação de absoluto e totalidade, sem tombar, porém, na tentação da intuição intelectual, à maneira de Schelling, nem na concepção de uma dialéctica disciplinar e negativa, como seria o caso de Kant, na visão que dele traçava Hegel.

23 "Die Erscheinung ist das Entstehen und Vergehen, das selbst nicht entsteht und vergeht, sondern an sich ist und die Wirklichkeit und Bewegung des Lebens der Wahrheit ausmacht. Das Wahre ist so der bacchantische Taumel", Phänomenologie des Geistes, Werke, Vol. 3, p. 46 . 
Pelo contrário, para Hegel, só ao tornar-se dialéctica, ao pensar o impensável, aquilo que exorbitava do campo da experiência regido pelas categorias do entendimento, ao ascender a uma posição hegemónica e não meramente reguladora, ao transcender e unificar as diferenças entre os seus diversos 'interesses', poderia a razão ir mais longe do que a estatigrafia imobilista da representação, para atingir a totalidade do Ser e da realidade na espiritualidade do sistema.

Para o jovem Nietzsche, o caminho da razão, tal como a concebiam as diversas variantes do idealismo europeu, havia esgotado as suas possibilidades. A busca de uma metafísica de artista traduzia esse diagnóstico de fracasso quanto às esperanças hegelianas na capacidade de a razão poder cumprir a sua vocação de totalidade e absoluto.

Ao pensarem o todo como devir e dilaceração, ao tentarem compreender a instabilidade das formas reais à luz do enigma do tempo, Hegel e Nietzsche vão enfrentar a dimensão fundamental de todo o pensamento filosófico da totalidade, vão encontrar o mistério da contradição e da diferença.

Contudo, para Hegel, a contradição e o ‘delírio báquico', a dilaceração trágica do que parecia estável e duradouro remete para uma ordem mais elevada que tudo engloba e organiza, pois o ponto de vista racional que capta a organização capta também o seu sentido último. Para Nietzsche, muito diversamente, a contradição assinala o carácter pletórico da realidade, o contraste entre o nosso olhar e a transbordante exuberância dos entes. Em Nietzsche, a consciência é uma heroína lançada nas rotas de uma infindável odisseia, um Ulisses sem Ítaca nem Penélope. Nada de definitivo ou superior poderá tranquilizar a consciência face ao inexpugnável mistério da morte e do mal. Não há teodiceias sagradas ou laicas com valor de verdade. Nenhuma economia de sentido poderá reconhecer e superar, simultaneamente, o sentido trágico da existência.

A necessidade de tornar inteligível o mundo leva Hegel a encerrá-lo na magnífica paisagem de uma vasta teleologia, que, usando a terminologia de NT, poderíamos classificar como apolínea, e na qual o próprio devir acaba por ser reconduzido à perenidade do Ser. A faceta trágica do mundo é destacada, numa primeira instância, para logo ser negada sob o império de um logos dialéctico. Para Nietzsche, por seu turno, o problema maior consiste não na eliminação do trágico através da interposição de uma ordenação conceptual portadora de sentido, mas sim em compreender como a dimensão trágica da existência é um sinal de abertura para novos sentidos, para e elevação da vida humana ao horizonte de novas possibilidades. A condição trágica não deveria ser entendida apenas como sofrimento e dor, pois ela contém, igualmente, as dimensões ocultas do jogo, do riso lúdico, da espontaneidade criadora.

Para Nietzsche não importa 'salvar' os indivíduos da condição trágica da existência, através de uma renúncia ética, como em Schopenhauer, nem 'resolver' o desafio metafísico dessa condição no seio de uma ontologia dialéctica, como no caso de Hegel. Para Nietzsche, a tarefa em NT, mas sobretudo na missão filosófica patente nas quase duas décadas de reflexão posterior, consiste em aprofundar e radicalizar afirmativamente as múltiplas facetas positivas da condição trágica. No múltiplo e complexo rosto dessa condição abrigava-se o enigma maior que une destino e liberdade.

\section{$\S 6$. O que significou $O$ Nascimento da Tragédia para o curso posterior da obra de Nietzsche?}

Em NT Nietzsche avança por um terreno problemático, que a atmosfera romântica, as ligações com o círculo de Wagner, a reverência para com Schopenhauer, e os próprios conflitos interiores não resolvidos do filósofo, impediriam, nos anos mais próximos, de um aprofundamento mais exaustivo.

NT foi, simultaneamente, a semente de uma nova cosmovisão e a confirmação de uma encruzilhada, de cuja decisão dependeria o desenvolvimrnto posterior da obra do jovem pensador germânico. 
Como vimos, o caminho onde se insere NT encontra-se dominado por uma amplíssima meditação sobre as características fundamentais da cultura grega. Nessa reflexão, Nietzsche exercita aquela que será uma das suas tarefas espirituais permanentes: o olhar crítico sobre a cultura europeia contemporânea, sobre a "modernidade" (Modernität). Nessa crítica abrigar-se-á a constelação temática que podemos encontrar no interior de um dos tópicos centrais do Nietzsche da maturidade: "a inversão de todos os valores" (Umwerthung aller Werthe) ${ }^{24}$.

A crítica da modernidade, muitas vezes apoiada num confronto com a idealização do mundo helénico, assume sempre uma postura emancipadora e libertadora:

"Por isso na Antiguidade os indivíduos eram mais livres, pois os seus objectivos estavam mais próximos e eram mais tangíveis. O homem moderno, pelo contrário, é cruzado por todo o lado pelo infinito, como Aquiles, o dos pés rápidos, no paradoxo de Zenão: o infinito trava-o, ele nem sequer apanhará a tartaruga"25.

Por outro lado, o estudo da tragédia grega havia revelado um mundo desconhecido, tornado invisível por quase dois mil anos de metafísica e cristianismo: o universo da realidade sensível e efémera, da experiência dos sentidos, do corpo, do sofrimento e da alegria, da terra e da coragem.

A exaltação da vida, e não a sua condenação como ocorria com Schopenhauer, era a hipótese de trabalho que o jovem Nietzsche retirava como herança permanente do seu texto de 1872, e da oposição dinâmica entre as forças apolíneas e dionisíacas. Estes símbolos seriam doravante entendidos como princípios para a reconstrução da tradição intelectual e histórica do Ocidente, bem como vigorosas figuras prospectivas ao serviço de um novo futuro cultural para a Europa.

Em NT, o texto aparentemente mais alemão do seu autor, desenvolveu Nietzsche uma visão pan-europeia do destino da cultura, que nem a febre nacionalista do seu tempo jamais conseguiu subjugar. Será como europeu que ele desenvolverá as traves mestras da sua grandiosa e inacabada teoria do niilismo (Nihilismus), que consiste, no fundo, e em certa medida, no prolongamento da crítica à transição das cosmovisões que vão do platonismo e socratismo, visados em NT, até à emergência da sociedade tecnocientífica e industrial moderna com as suas ideologias secularizadas do progresso. O niilismo será o desvendamento das ilusões e dos medos culturais do Ocidente, transformados nos ícones milenares e milenaristas, nos bezerros de oiro, que a acutilante crítica nietzscheana, tal como se fora um novo Moisés, procurará despedaçar.

A oposição entre o 'homem teórico', subordinado a uma economia intelectualista e redutora de valores, e o 'homem trágico', afirmador da existência e criador de valores ao seu serviço, que perpassa nas páginas de NT, também não será abandonada jamais.

Não é a figura do "super-homem" (Übermensch) a re-escrita desse homem trágico, corajoso e audaz? Um novo sujeito capaz de aceitar a morte de Deus e a responsabilidade de dar sentido, a partir de dentro e de si, a um mundo que corre o risco de de desorganizar caoticamente.

24 KS, Vol.12, 10 [18], p. 464. Uma interpretação vasta do lugar de Nietzsche e do NT no debate estético sobre modernidade e pós-modernidade, sobretudo no que concerne à transformação da estética de Kant na metafísica da arte de Schopenhauer pode encontrar-se em: Nuno Nabais, Metafísica do trágico. Ensaios sobre Nietzsche, Lisboa, Relógio D’Água, 1997, pp. 15-72. Agradeço, igualmente, a Nuno Nabais as críticas e sugestões apresentadas ao original deste texto, que enriqueceram a sua versão final.

25 "Deshalb waren die Individuen in Alterthums freier, weil ihre Ziele näher und greifbarer waren. Der modern Mensch ist dagegen überall gekreuzt von der Unendlichkeit, wie der schnellfüssige Achill im Gleichnisse des Eleaten Zeno: die Unendlichkeit hemmt ihn, er holt nicht einmal die Schildkröte ein., Homer's Wettkampf, KS, Vol. 1, p. 790). 
E a "vontade de poder" (Wille zur Macht) poderá ser algo mais, na sua essência, do que o princípio fundamental de um novo enraizamento da filosofia, uma reconstrução imanente da arquitectura do mundo? A vontade de poder contém a promessa e um projecto de uma cosmovisão em que o ponto de Arquimedes não se encontra: nem num Deus trancendente, acessível à razão, à paixão mística, ou olimpicamente oculto; nem num plano ideal, descrito com os predicados de uma eternidade e imobilidade, em tudo contrário ao domínio do espaço, do tempo da sensibilidade, que, mais do que fundamentar acabariam por denegrir e desvalorizar.

O grande objectivo da obra de Nietzsche é a realização de um grande investimento axiológico, uma radical revalorização do plano fenoménico da existência efectiva e concreta. Nessa medida, quando no Outono de 1887, Nietzsche, numa nota inédita, procura combinar Espinosa e Leibniz numa fórmula de aceitação suprema do mundo-tal-como-ele-é, é ainda os ecos travestidos do pessimismo de 1872 que aí encontramos.

Escrevia Nietzsche a propósito da necessidade de uma nova teodiceia (na verdade uma geodiceia):

"Este pessimismo de força termina numa teodiceia, quer dizer, numa anuência absoluta concedida ao mundo, mas pelas razões que haviam sido dadas anteriormente para the ter dito não"26.

Por último, qual será o lugar teórico da cosmovisão de Nietzsche onde melhor se prolongam e realizam as sementes de NT? Estou convencido que esse lugar é precisamente o ponto de encontro entre expressão racional e expressão simbólica, que Nietzsche associava à necessidade de reabilitação e renovação da imaginação mítica na cultura contemporânea.

Não será a doutrina do "eterno retorno do mesmo" (ewige Wiederkunft des Gleiches) o mito moderno da necessidade de regressar à Terra, ao "sentido da Terra" (Erdsinn) depois de um longo exílio no reino metafisico das sombras?

26 "Auch dieser Pessimismus der Stärke endet mit einer Theodizee d.h. mit einem absoluten Jasagen zu der Welt, aber um der Gründe willen, auf die hin man zu ihr ehemals Nein gesagt hat", KS, Vol. 12, 10 [21], pp. 467-468. 
